\title{
Effect of Employee Empowerment on Lecturer Performance
}

\author{
G. Agustina ${ }^{1, *}$ S.E. Nurhayati ${ }^{2,}$ L.A. Wibowo ${ }^{3,}$ Nandang Djunaedi ${ }^{4}$, Feby Febrian ${ }^{5}$ \\ ${ }^{1}$ Universitas Pendidikan Indonesia \\ ${ }^{2}$ Universitas Pendidikan Indonesia \\ ${ }^{3}$ Universitas Pendidikan Indonesia \\ ${ }^{4}$ Universitas Winaya Mukti \\ ${ }^{5}$ Universitas Winaya Mukti \\ ${ }^{*}$ Corresponding author. Email: granit82.ga@gmail.com
}

\begin{abstract}
This study aims to analyze the effect of employee empowerment on the performance of lecturers at one private university in Bandung. In this study there were two variables, namely employee empowerment and performance. The method used in this research was descriptive and verification methods. The data used were primary and secondary data generated through observation, interviews, questionnaires and literature. The hypothesis of this study was that there was an effect of employee empowerment on lecturer performance. To measure the effect of these variables, simple linear regression and the coefficient of determination were used through the SPSS 24 application software system for windows. The study was conducted using a questionnaire distributed to all students at one of the private universities in Bandung by using the Google form. Based on the results, it can be concluded that employee empowerment affected the lecturers' performance. This research is beneficial as it can make a positive contribution to universities throughout Indonesia in empowering the lecturers' abilities and expertise.
\end{abstract}

Keywords: Employee Empowerment, Lecturer Performance.

\section{INTRODUCTION}

The success of a tertiary institution emphasizes the role of lecturers in realizing good quality graduates and their potential to compete in society to meet its various needs. A tertiary institution often experiences problems in improving the quality of its organization which results in a lack of interest people due to the role of lecturers or teaching staff who are still lack of quality and qualifications so that there is a deterioration in improving their learning performance. Higher education management has the responsibility to be able to empower teaching staff or lecturers when they experience various problems ranging from indiscipline, unpreparedness, disappointment, dissatisfaction, injustice and the occurrence of unfair competition for a group of people. While the performance of the lecturer concerns all the activities carried out by the teaching staff to achieve the desired goals. In relation to the teaching staff, the answers that lecturers make are basically more focused on the behavior of the teaching staff in their work, as well as about the effectiveness of the teaching staff is the extent to which the performance can affect students. This research was conducted in the hope that the quality of teaching and learning throughout Indonesia, especially lecturers, could be further improved by having quality that could be used as a benchmark for universities in Indonesia and throughout the world.

In this research, it is known that a lecturer who is empowered properly will be able to complete his assignments in accordance with his knowledge and abilities, both in lecturing activities or implementation in social activities. Optimal empowerment of lecturers can improve their performance. This is because the empowerment of a lecturer can emerge while increasing the potential that exists within each lecturer so that it will be able to influence the improvement of the quality of education in the tertiary institution. In addition, with employee empowerment, it is expected that the performance of lecturers will improve in making various 
efforts that are full of innovation and in the field of the knowledge they teach so that the learning process becomes more passionate and full of enthusiasm.

In previous studies conducted by [1], job standardization had a negative effect on employees' innovative behavior. In addition, psychological empowerment of employees mediated the effect of work standardization on innovative behavior. It was also stated that the leadership evaluation of lecturers ' performance was included in the moderate / moderate category, lecturers' responses to empowerment in the moderate / moderate category, the competency test results were included in the high category while the lecturers responded to job satisfaction in the moderate/moderate category. Empowerment, competence, and job satisfaction had a positive and significant direct effect on the performance of lecturers [2].

According to [3], empowerment is an increase in the capacity of employees to make decisions. Then according to [4] empowerment refers to the increasing of employee's performance that influences his work responsibilities by giving the employee the authority to take decisions related to his work without the need to ask permission from his superiors. According to [5], each agency must be able to invite its employees to provide a form of communication model that is appropriate to its needs to create a better performance. According to [6], performance is a track record of the achievement of the work function or activity during a period.

The purpose of this study was to identify the effect of employee empowerment on lecturer performance to strengthen theories related to the relationship of empowerment and performance.

Reference [7] conducted a research on lecturer performance concerning all activities carried out by the concerned (teaching staff) to achieve the desired goals.

\section{METHODS}

The method used in this research was descriptive analysis to identify the effect of employee empowerment on lecturer performance. This research was conducted at a national private university in West Java using a nonprobability sampling technique, namely saturated sampling (census). The number of lecturers involved in this study were 100 people who were all made respondents. The hypothesis in this study was that employee empowerment affects the performance of lecturers in the XYZ university environment. To measure the effect of these variables, Simple Linear Regression was used through the SPSS 24.0 application.

\section{RESULTS AND DISCUSSION}

Based on Table 1, it is known that all indicators of employee empowerment have a calculated $r$ value greater than $r$ table which confirms its validity.

Table 1. Validity Test of Employee Empowerment

\begin{tabular}{|l|l|l|l|}
\hline & $\begin{array}{c}\text { Corrected Item-Total } \\
\text { Correlation (r hitung) }\end{array}$ & r table & Description \\
\hline EM1 & 0,594 & 0,197 & Valid \\
\hline EM2 & 0,519 & 0,197 & Valid \\
\hline EM3 & 0,501 & 0,197 & Valid \\
\hline EM4 & 0,591 & 0,197 & Valid \\
\hline EM5 & 0,514 & 0,197 & Valid \\
\hline EM6 & 0,529 & 0,197 & Valid \\
\hline EM7 & 0,498 & 0,197 & Valid \\
\hline EM8 & 0,490 & 0,197 & Valid \\
\hline EM9 & 0,638 & 0,197 & Valid \\
\hline EM10 & 0,605 & 0,197 & Valid \\
\hline
\end{tabular}

Based on Table 2, it is known that all indicators of Lecturer Performance have a calculated $r$ value greater than $r$ table which confirms its validity.

Table 2. Validity Test of Lecturer Performance

\begin{tabular}{|l|l|l|l|}
\hline & $\begin{array}{c}\text { Corrected Item-Total } \\
\text { Correlation (r hitung) }\end{array}$ & r table & Description \\
\hline LP1 & 0,494 & 0,197 & Valid \\
\hline LP2 & 0,419 & 0,197 & Valid \\
\hline LP3 & 0,503 & 0,197 & Valid \\
\hline LP4 & 0,499 & 0,197 & Valid \\
\hline LP5 & 0,516 & 0,197 & Valid \\
\hline LP6 & 0,531 & 0,197 & Valid \\
\hline LP7 & 0,500 & 0,197 & Valid \\
\hline LP8 & 0,496 & 0,197 & Valid \\
\hline LP9 & 0,545 & 0,197 & Valid \\
\hline LP10 & 0,587 & 0,197 & Valid \\
\hline LP11 & 0,487 & 0,197 & Valid \\
\hline LP12 & 0,511 & 0,197 & Valid \\
\hline LP13 & 0,521 & 0,197 & Valid \\
\hline LP14 & 0,490 & 0,197 & Valid \\
\hline & & & \\
\hline
\end{tabular}

Based on Table 3, it is known that all variables have a reliability level above 0.6 which means that it is very reliable.

Table 3. Reliability

\begin{tabular}{|l|l|l|l|}
\hline \multicolumn{1}{|c|}{ Variabel } & $\begin{array}{c}\text { Cronchbach's } \\
\text { Alpha }\end{array}$ & Correlation & Description \\
\hline $\begin{array}{l}\text { Employee } \\
\text { Empowerment }\end{array}$ & 0,748 & 0,6 & Reliabel \\
\hline Lecture performance & 0,780 & 0,6 & Reliabel \\
\hline
\end{tabular}

Based on Table 4, it is known that the commonly used cutoff value is a tolerance value above 0.10 or equal to a VIF value below 10. It can be concluded that the EM and $\mathrm{KD}$ variables have a significant linear relationship.

Table 4. Linear Regression

\begin{tabular}{|l|l|c|c|c|}
\hline \multicolumn{5}{|c|}{ Coefficients $^{\text {a }}$} \\
\hline Model & $\begin{array}{l}\text { Unstandardize } \\
\text { d Coefficients }\end{array}$ & $\begin{array}{c}\text { Standardize } \\
d \\
\text { Coefficients }\end{array}$ & $t$ & Sig. \\
\hline
\end{tabular}




\begin{tabular}{|c|c|c|c|c|c|c|}
\hline & $B$ & $\begin{array}{c}\text { Std. } \\
\text { Error }\end{array}$ & Beta & & \\
\hline \multirow[t]{2}{*}{1} & (Constant & 9.806 & 2.091 & & 4.689 & $\begin{array}{l}.00 \\
0\end{array}$ \\
\hline & EM & 1.140 & .049 & .921 & $\begin{array}{l}23.46 \\
2\end{array}$ & $\begin{array}{l}.00 \\
0\end{array}$ \\
\hline
\end{tabular}

Based on Table 5, it is known that the correlation coefficient between EM is 0.849. This shows a close relationship between EM and LP. This value is included in the medium criteria and shows a positive direction of the relationship.

Table 5. Correlation Coefficients

\begin{tabular}{|l|c|c|c|c|}
\hline \multicolumn{5}{|c|}{ Model Summary } \\
\hline Model & $\boldsymbol{R}$ & $\boldsymbol{R}$ Square & $\begin{array}{c}\text { Adjusted } \boldsymbol{R} \\
\text { Square }\end{array}$ & $\begin{array}{c}\text { Std. Error of the } \\
\text { Estimate }\end{array}$ \\
\hline 1 & $.849 \mathrm{a}$ & .720 & .718 & 1.948 \\
\hline
\end{tabular}

a. Predictors: (Constant), EM

The magnitude of the relationship between employee empowerment and lecturer performance is $84.9 \%$ based on the interpretation that the value of 0.849 is included in the category of very strong relationships. The contribution of the influence of employee empowerment on lecturer performance is $72 \%$ and the remaining $28 \%$ is influenced by other factors. Employee empowerment influences Lecturer Performance with the tcount value of 4.689>t table 1.984 so it can be concluded that Ho is rejected and $\mathrm{Ha}$ is accepted. This means that employee empowerment significantly influences Lecturer Performance in National Private Universities. The results of this study reinforce the theories related to the relationship of empowerment and performance. According to [8], there is an influence of empowerment on work quality (performance). It was also stated that the leadership evaluation of UNWIR lecturers' performance was included in the moderate / moderate category, lecturers' responses to empowerment in the moderate / moderate category, the competency test results were included in the high category while the lecturers' response to job satisfaction was in the moderate / moderate category. Empowerment, competence, and job satisfaction had a positive and significant direct effect on the performance of UNWIR lecturers [2].

\section{CONCLUSIONS}

Through employee empowerment, it is expected that the performance of a lecturer will increase in making various efforts that are full of innovation and in the field of science that they are in, so that the teaching and learning process becomes more passionate and full of enthusiasm.

\section{ACKNOWLEDGMENT}

We would like to express our deepest gratitude to the University of Indonesian Education, Faculty of Economics and Business, University of Winaya Mukti lecture Dr. (C) Drs Nandang Djunaedi., MM who has facilitated and helped the research from the beginning until its completion.

\section{REFERENCES}

[1] H.-F. Luoh, S.-H. Tsaur, and Y.-Y. Tang, "Empowering employees: job standardization and innovative behavior," International J. of Contemporary Hospitality Management, vol. 26, no. 7, pp. 1100-1117, 2014.

[2] Sumardi and Surianti, "The effect of empowerment, competence, and job satisfaction on the performance of Indramayu Wiralodra University lecturers," Investment J., vol. 5, pp. 78-104, 2019.

[3] R. Huq, The Psycology of Employee Empowerment: Concepts, Critical Themes, and a Framework for Implementation, Gower Publishing, Ltd, 2015, pp. 152.

[4] R. Kapoor, J. Paul, and B. Halder, Service Marketing: concepts, Critical Themes, and A Framework for Implementation, 2011, pp. 33.

[5] N. Djunaedi, F. Febrian, G. Agustina, H. Suryani, and R. Nalibratawati, "Downward communication model to improve employee performance," International J. of Psychosocial Rehabilitation, vol. 24, no. 4, 2020 .

[6] A.J. Bernardin, H. John, and B. Russel, Human Resource Management, New York: McGraw-Hill, 2010, pp. 222.

[7] H.B. Uno, Profesi Kependidikan, Jakarta: Bumi Aksara, 2008

[8] K.M. York, Applied Human Resource Management: Strategic Issues and Experiential Exercises, Sage Publications, 2009. 